\title{
UPAYA PENINGKATAN PENDAPATAN MASYARAKAT MELALUI PROGRAM PELATIHAN TATA KECANTIKAN RAMBUT (Studi kasus pada peserta pelatihan di LKP HENNY'S Kota Cimahi)
}

\author{
1Ananda Subagja, ${ }^{2}$ Tita Rosita \\ 1,2IKIP Siliwangi \\ 1anandasubagja2@gmail.com
}

\begin{abstract}
ABSTRAK
Pertumbuhan suatu wilayah akan berkembang jika sumber daya manusia dapat dikembangkan dengan baik dalam asfek kognitif, afektif, psikomotor, untuk menerapkannya yaitu dari segi pendidikan dan pelatihan. pelatihan adalah upaya pembelajaran, yang diselenggarakan oleh organisasi (instansi pemerintah, lembaga swadaya masyarakat, perusahaan, dan lain sebagainya) untuk memenuhi kebutuhan atau untuk mencapai tujuan organisasi. Penulis memilih lokasi penelitian di LKP Henny's dengan warga belajar yang mengikuti pelatihan berjumlah 40 orang, serta tutor/tenaga belajar berjumlah 4 orang. Metode yang digunakan dalam penelitian ini adalah kualitatif. Pendekatan kualitatif digunakan karena fokus penelitian ini adalah pengungkapan dari proses. Salah satu keterampilan yang di selenggarakan melalui pendidikan kecakapan hidup adalah keterampilan Tata Kecantikan Rambut. Tata kecantikan rambut salah satu bentuk pendidikan yang dikembangkan pada pendidikan nonformal untuk melayani kebutuhan belajar masyarakat. Keterampilan tata kecantikan rambut sangat menguntungkan dan merupakan suatu kegiatan yang bergerak di bidang jasa. Dengan demikian dapat dikemukakan bahwa pelatihan keterampilan tata kecantikan rambut sangat bermanfaat bagi masyarakat, khusus nya masyarakat yang memiliki tingkat ekonomi rendah.
\end{abstract}

Kata Kunci :Keterampilan, Pelatihan, Tata Kecantikan Rambut

\section{PENDAHULUAN}

Sumber daya manusia yang sangat berkualitas pada saat ini sangat dibutuhkan untuk kemajuan dan pertumbuhan suatu wilayah. Pertumbuhan suatu wilayah akan berkembang jika sumber daya manusia dapat dikembangkan dengan baik dalam asfek kognitif, afektif, psikomotor, untuk menerapkannya yaitu dari segi pendidikan dan pelatihan. Menurut (Salim, 1996) pengertian Kualitas Sumber Daya Manusia sebagai berikut : Kualitas Sumber Daya Manusia adalah nilai dari perilaku seseorang dalam mempertanggungjawabkan semua perbuatannya baik dalam kehidupan pribadi maupun kehidupan bermasyarakat dan berbangsa. Pendidikan menjadi kunci pembangunan,dengan pendidikan diharapkan dapat tercapai sumber daya manusia yang berkualitas. Selain itu pendidikan juga menjadi salah satu faktor yang sangat mempengaruhi terhadap laju pembangunan suatu bangsa. Dan pendidikan pun merupakan investasi dalam kehidupan manusia yang akan sangat menentukan kualitas sumber daya manusia. Peranan pendidikan pada era globalisasi yaitu mampu membentuk masyarakat yang aktif, kreatif, dan dinamis mampu mengembangkan potensi diri dan lingkungan kearah kemandirian. 
Pendidikan adalah usaha sadar dan terencana untuk mewujudkan suasana belajar dan proses pembelajaran agar peserta didik secara aktif mengembangkan potensi dirinya untuk memiliki kekuatan sipiritual, keagamaan, pengendalian dirinya, kepribadian, kecerdasan, akhlak mulia serta keterampilan yang diperlukan dirinya, masyarakat,bangsa dan negara. Lebih lanjut undang-undang menetapkan terdapat tiga jalur pendidikan yaitu pendidikan formal, pendidikan non formal, dan pendidikan informal. (UUSPN No. 20 tahun 2003).

Menurut Coombs (Sudjana, 2010) Pendidikan Non Formal adalah setiap kegiatan terorganisasi dan sistematis diluar sistem persekolahan yang mapan, dilakukan secara mandiri atau merupakan bagian penting dari kegiatan yang lebih luas, yang sengaja dilakukan untuk melayani peserta didik tertentu didalam mencapai tujuan belajarnya. Tujuan pendidikan life skill secara khusus bila dirinci adalah sebagai berikut: a) melaksanakan program-program pendidikan dan pelatihan yang mampu mengembangkan ketrampilan, keahlian dan kecakapan serta nilai-nilai keprofesian untuk mendorong produktivitas sebagai tenaga kerja yang handal atau kemandirian berusaha. b) Memberikan kesempatan kepada masyarakat untuk mengikuti program khusus berbasis kompetensi, serta fasilitas penempatan kerja pada dunia usaha/industri dan /atau berusaha mandiri.

Menurut (Kamil, 2010) Tujuan peningkatan kecakapan hidup adalah untuk : (1) mengaktualisasikan potensi masyarakat sehingga dapat digunakan untuk memecahkan problema yang dihadapi, (2) memberikan kesempatan kepada masyarakat dan lembaga masyarakat untuk mengembangkan program pembangunan dan pemberdayaan masyarakat yang fleksibel, sesuai dengan prinsip pembangunan masyarakat, dan (3) mengoptimalkan pemanfaatan sumber daya di lingkungan masyarakat, dengan memberi peluang pemanfaatan sumber daya yang ada di masyarakat, sesuai dengan prinsip manajemen pembangunan.

Program pendidikan kecakapan hidup melalui Lembaga Kursus Dan Pelatihan (LKP) merupakan upaya nyata untuk mendidik dan melatih warga masyarakat di daerah perkotaan/pedesaan agar menguasai keterampilan fungsional praktis yang dapat dimanfaatkan untuk bekerja baik di sektor formal maupun informal sesuai dengan peluang kerja (job opportunities) yang ada, dan usaha mandiri atau membuka peluang usaha.

Menurut (Anwar, 2012) "Berpendapat, program pendidikan life skills adalah pendidikan yang dapat memberikan bekal keterampilan praktis, terpakai, terkait dengan kebutuhan pasar kerja, peluang usaha dan potensi ekonomi atau industri yang ada di masyarakat". Program keterampilan Tata Kecantikan Rambut merupakan suatu keterampilan yang sangat diminati oleh semua kalangan, maka dapat di identifikasi tiga masalah sebagai berikut:

1. Banyaknya masyarakat yang tidak memiliki pekerjaan.

2. Banyaknya masyarakat yang hidup dengan tingkat ekonomi menengah kebawah.

3. Banyaknya masyarakat yang belum memiliki keterampilan yang bisa diunggulkan

Di dalam kehidupan nyata salah satu upaya yang perlu dilakukan adalah mendekatkan pendidikan (kegiatan belajar mengajar) dengan kehidupan nyata yang memiliki nilainilai preservative dan progresif sekaligus melalui pengintensifan dan pengefektifitasan pendidikan kecakapan hidup, sehingga penting sekali pendidikan kecakapan hidup 
dilakukan untuk meningkatkan keterampilan, pengetahuan dan sikap masyarakat di bidang pekerjaan/usaha sesuai dengan bakat, minat sesuai potensi lingkungannya sehingga mereka memiliki bekal kemampuan untuk bekerja ataupun usaha mandiri untuk meningkatkan kualitas hidupnya yang akan berdampak kepada pendapatannya.

Memberikan pelayanan pendidikan sepanjang hayat (lifelong learning) kepada masyarakat, munculah berbagai konsep mengenai pendidikan non formal untuk diselenggarakan, banyaknya pihak yang membahas mengenai pendidikan non formal yang dianggap sebagai pendidikan yang mampu memecahkan berbagai masalah layanan pendidikan masyarakat, salah satunya dengan kegiatan pelatihan. Istilah pelatihan tidak terlepas dari latihan karena keduanya mempunyai hubungan yang erat, latihan adalah kegiatan atau pekerjaan melatih untuk memperoleh kemahiran atau kecakapan. Sedangkan tujuan kegiatan pelatihan untuk meningkatkan pengetahuan dan keterampilan seseorang agar mereka yang dilatih mendapat pengetahuan dan keterampilan dalam menghadapi permasalahan yang dihadapi sesuai harapan dan tujuan yang di inginkan mengikuti kegiatan pelatihan.

Pelatihan adalah bagian dari pendidikan yang merupakan sarana pembinaan dan pengembangan karir serta salah satu upaya untuk meningkatkan kualitas sumber daya manusia sesuai dengan kebutuhan pekerjaan. Salah satu program pendidikan kecakapan dan keterampilan tentang tata kecantikan rambut merupakan sebagai bekal bagi peserta didik untuk terjun di masyarakat atau usaha mandiri.

Tata Kecantikan Rambut adalah sebuah program yang telah berkembang dengan perubahan-perubahan yang sangat pesat, yang terjadi dalam kurun waktu 20 tahun terakhir. Adanya perubahan kurikulum dasar menjadi kurikulum berbasis kompetensi merupakan bukti perkembangan dimaksud dibuktikan dengan telah tersusunnya S.K.K.N.I. (Standar Kompetensi Kerja Nasional Indonesia) bidang Tata Kecantikan Rambut yang disusun oleh para ahli dari Asosiasi Profesi Kecantikan, Para Pakar, Produsen Kosmetika, Instansi Depdiknas, Depnakertrans dll. Program kursus dan pelatihan tata kecantikan rambut adalah program belajar jangka pendek yang sangat efisien dan efektif, karena dengan waktu belajar yang relatif singkat peserta didik dapat dengan cepat menguasai kecakapan hidup dibidang tata kecantikan rambut.

Untuk mendapatkan sertifikat sebagai penata rambut yang handal, peserta didik harus menyelesaikan 3 kelas yang telah ditentukan, yaitu tingkat dasar, tingkat terampil, dan tingkat mahir dengan materi yang berbeda terutama pada materi keterampilannya sesuai dengan kurikulum yang berlaku. Kurikulum kursus kini sudah memakai kurikulum berbasis kompetensi, dimana untuk setiap unit kompetensi telah disusun kompetensi dasar dan indikatornya yang mengandung aspek pengetahuan, keterampilan dan sikap yang harus dimiliki oleh peserta didik kursus tata kecantikan rambut. Sungguh suatu kompetensi yang lengkap bagi peserta didik didalam menjawab tantangan zaman yang kian maju, dimana tidak hanya keterampilan yang diminta, tapi juga ilmu pengetahuan dan sikap prilakunya dalam menghadapi persaingan di dunia industri dan dunia usaha, khususnya tata kecantikan rambut. 


\section{LANDASAN TEORI}

\section{Pendapatan}

Dalam pengertian umum pendapatan adalah hasil pencaharian usaha. (Boediono, 1992) mengemukkan bahwa pendapatan adalah hasil dari penjualan faktor-faktor produksi yang dimilikinya kepada sektor produksi. Pendapatan adalah hasil berupa uang atau materi lainnya yang dapat dicapai dari pada penggunaan faktor-faktor produksi.

Berdasarkan kedua pengertian di atas dapat disimpulkan bahwa pendapatan merupakan nilai dari seluruh barang dan jasa yang dihasilkan oleh suatu badan usaha dalam suatu periode tertentu. Dengan demikian maka yang dimaksud dengan pendapatan jasa adalah nilai dari seluruh jasa yang dihasilkan suatu badan usaha dalam suatu periode tertentu.

\section{Pelatihan}

Memberikan pelayanan pendidikan sepanjang hayat (lifelong learning) kepada masyarakat, munculah berbagai konsep mengenai pendidikan non formal untuk diselenggarakan, banyaknya pihak yang membahas mengenai pendidikan non formal yang dianggap sebagai pendidikan yang mampu memecahkan berbagai masalah layanan pendidikan masyarakat, salah satunya dengan kegiatan pelatihan. Istilah pelatihan tidak terlepas dari latihan karena keduanya mempunyai hubungan yang erat, latihan adalah kegiatan atau pekerjaan melatih untuk memperoleh kemahiran atau kecakapan. Sedangkan tujuan kegiatan pelatihan untuk meningkatkan pengetahuan dan keterampilan seseorang agar mereka yang dilatih mendapat pengetahuan dan keterampilan dalam menghadapi permasalahan yang dihadapi sesuai harapan dan tujuan yang di inginkan mengikuti kegiatan pelatihan.

Pelatihan adalah bagian dari pendidikan yang merupakan sarana pembinaan dan pengembangan karir serta salah satu upaya untuk meningkatkan kualitas sumber daya manusia sesuai dengan kebutuhan pekerjaan. Pada kajian ini penulis memfokuskan pada makna pelatihan. Para ahli banyak berpendapat tentang arti dan definisi pelatihan, namun dari berbagai pendapat tersebut pada prinsipnya tidak jauh berbeda.

Goldstsein dan Gressner (1988) dalam (Kamil, 2010) mendefinisikan pelatihan sebagai usaha sistematis untuk menguasai keterampilan, peraturan, konsep, ataupun cara berperilaku yang berdampak pada peningkatan kinerja. Sebagai hasil pelatihan, peserta diharapkan mampu merespon dengan tepat dan sesuai situasi tertentu. Seringkali pelatihan dimaksudkan untuk memperbaiki kinerja yang langsung berhubungan dengan situasinya.

\section{Kecakapan hidup}

Konsep kecakapan hidup atau life skills merupakan salah satu fokus analisis dalam pengembangan kurikulum pendidikan yang menekankan pada kecakapan hidup atau bekerja. Kecakapan hidup memiliki makna yang lebih luas dari employability skills dan vocational skills. Keduanya merupakan bagian dari program life skills. Istilah hidup menurut (Anwar, 2012) adalah tidak semata-mata memiliki kemampuan tertentu saja, namun harus memiliki kemampuan dasar pendukungnya secara fungsional seperti, membaca, menulis, menghitung, merumuskan dan memecahkan masalah, mengelola sumber daya, bekerja dalam tim, terus belajar di tempat kerja dan mempergunakan teknologi. 


\section{Tata Kecantikan Rambut}

Tata kecantikan rambut adalah sebuah program yang telah berkembang dengan perubahan-perubahan yang sangat pesat, yang terjadi dalam kurun waktu 20 tahun terakhir. Adanya perubahan kurikulum dasar menjadi kurikulum berbasis kompetensi merupakan bukti perkembangan yang dimaksud, dibuktikan dengan telah tersusunnya S.K.K.N.I. (Standar Kompetensi Kerja Nasional Indonesia) bidang Tata Kecantikan Rambut yang disusun oleh para ahli dari Asosiasi Profesi Kecantikan, para pakar, produsen kosmetika, Instansi Depdiknas, Depnakertrans, dan lain-lain (kurikulum terlampir). Program kursus dan pelatihan tata rambut adalah program belajar jangka pendek yang sangat efisien dan efektif, karena dengan waktu belajar yang relatif singkat peserta didik dapat dengan cepat menguasai kecakapan hidup dibidang tata kecantikan rambut.

Untuk mendapat sertifikat sebagai penata rambut yang handal, peserta didik harus menyelesaikan tiga kelas yang telah ditentukan, yaitu tingkat dasar, tingkat terampil, dan tingkat mahir. Dalam setiap tingkatan, materi yang diberikan berbeda terutama pada materi keterampilannya sesuai dengan kurikulum yang berlaku. Kurikulum kini sudah memakai kurikulum berbasis kompetensi, dimana untuk setiap unit kompetensi telah disusun standar kompetensinya yang mengandung aspek pengetahuan, keterampilan dan sikap yang harus dimiliki oleh peserta didik kursus tata kecantikan rambut. Materi ajar yang diberikan meliputi materi teori penunjang dan keterampilan, serta materi praktek sesuai dengan tingkatannya. Secara keseluruhan materi teori adalah 30\% dan materi praktek 70\%. Sertifikasi penata rambut dilakukan atas dasar perkembangan keterampilan dari peserta didik, mulai dari tingkat terendah sampai tingkat berikutnya, Tata kecantikan rambut adalah suatu program yang mencetak sumber daya manusia yang handal dalam bidang tata rias rambut. Populasi masyarakat yang meningkat menyebabkan lebih banyak peluang pekerjaan bagi lulusan kursus dan pelatihan tata kecantikan rambut untuk melayani kebutuhan akan tenaga penata rambut. Tujuan yang sangat penting dalam program ini adalah memperoleh keahlian, baik secara teori maupun secara praktek dalam aspek-aspek desain tata kecantikan rambut.

\section{METODE PENELITIAN}

Penelitian ini menggunakan pendekatan kualitatif, pendekatan kualitatif digunakan karena fokus penelitian ini adalah pengungkapan dari proses, menurut Meleong dalam buku (Herdiansyah, 2010) mendefinisikan bahwa penelitian kualitatif adalah suatu penelitian ilmiah, yang bertujuan untuk memahami suatu fenomena dalam konteks sosial secara alamiah dengan mengedepankan proses interaksi komunikasi yang dalam antara peneliti dengan fenomena yang diteliti. Metode penelitian yang digunakan yaitu dengan metode deskriptif. Alasan peneliti menggunakan pendekatan kualitatif deskriptif, karena permasalahan yang dibahas dalam penelitian ini tidak berhubungan dengan angka-angka, akan tetapi menyangkut pendeskripsian, penguraian dan penggambaran suatu masalah yang sedang terjadi. Adapun teknik pengumpulan data, penulis menggunakan metode observasi, wawancara, dan dokumentasi. Penulis juga menggunakan pedoman wawancara dalam proses memperoleh keterangan untuk tujuan penelitian.

Penelitian ini dilaksanakan di LKP Henny's yang beralamat di Jl.Pesantren Nomor 36 A RT 01 RW 10 Kelurahan Cibabat Kecamatan Cimahi Utara. Subjek penelitian yang dipilih dalam penelitian ini adalah peserta pelatihan tata kecantikan rambut. 


\section{HASIL DAN PEMBAHASAN}

\section{Hasil}

\section{Pendapatan masyarakat sekitar LKP Henny's.}

Berdasarkan hasil wawancara dengan pimpinan LKP Henny's, pendapatan masyarakat di lingkungan sekitar tergolong minim. Hal ini di indikasikan oleh beberapa data formulir peserta pelatihan yang melampir kan Surat Keterangan Tidak Mampu (SKTM) sebagai persyaratan mengikuti pelatihan tersebut. Tidak hanya itu, bahkan $80 \%$ dari peserta pelatihan tata kecantikan rambut merupakan pengangguran tidak berpenghasilan. Senada dengan pendapat pimpinan LKP Henny's, hal ini juga dibenarkan oleh beberapa tokoh masyarakat sekitar seperti ketua RT 01 dan ketua RW 10 bahwa semenjak pabrik yang berada di sebrang LKP Henny's bangkrut kondisi ekonomi masyarakat RW 10 dapat dikatakan memprihatinkan karena umumnya pegawai pabrik tersebut merupakan masyarakat sekitar yang terpaksa di berhentikan dari pekerjaan nya. Sehingga banyak masyarakat yang beralih profesi menjadi pedagang, gojeg, ibu rumah tangga bahkan masih ada yang belum memiliki pekerjaan kembali.

\section{Pelaksanaan program tata kecantikan rambut.}

Pelatihan tata kecantikan rambut merupakan kegiatan yang digagas oleh pemerintah sebagai upaya meningkatkan kecakapan hidup masyarakat dan dilaksanakan oleh LKP Henny's selaku penyelenggara program. Program pelatihan ini dilaksanakan selama 1 bulan, yang terbagi menjadi 1 minggu pembelajaran teori, dan 3 minggu praktek. Adapun proses pelatihan tata kecantikan rambut di LKP Henny's adalah sebagai berikut; pembelajaran teori, pengenalan dasar mengenai tata kecantikan rambut, pengantar ilmu kewirausahaan, pengenalan bahan bahan dan alat kerja, pengenalan resiko bekerja, penanganan customer, handling complaint, dan lain-lain yang dilakukan selama seminggu. Lalu pembelajaran praktek yang dilakukan selama 3 minggu adalah mengaplikasikan teori yang sudah diajarkan untuk di praktekan terhadap rekan sekelompok. Mulai dari pengaplikasian bahan kerja,alat kerja, teknik memotong, creambath, catok, dll. Sumber daya manusia yang membina program tersebut sampai berhasil yaitu terdiri dari 3 orang tutor, 1 orang assisten, dan 1 orang administrasi.

Kegiatan tersebut diikuti oleh 40 orang peserta pelatihan sesuai dengan kapasitas nya. Namun pendaftar melebihi kapasitas dengan total pendaftar mencapai 87 orang. Hal ini menunjukan antusiasme masyarakat terhadap program pelatihan tersebut. Keinginan untuk belajar dan mengubah nasib menjadi modal kuat untuk mengikuti pelatihan tersebut.

\section{Hasil program tata kecantikan rambut dalam meningkatkan pendapatan masyarakat.}

Dari hasil penelitian yang telah dikemukakan tentang peningkatan pendapatan masyarakat melalui program pelatihan tata kecantikan rambut, keterampilan Tata Kecantikan Rambut sangat menguntungkan bagi masyarakat dan merupakan suatu kegiatan yang bergerak di bidang jasa. Keuntungannya disamping dapat melamar kerja di salon, juga dapat berwirausaha mandiri dengan membuka usaha salon. Peningkatan pendapatan yang diharapkan pada peserta didik setelah mengikuti proses pembelajaran keterampilan tata kecantikan rambut adalah bertambahnya pemasukan melalui hasil kerja baik itu melalui produk atau jasa dengan upah yang mereka terima. 
Dengan demikian melalui pembelajaran kursus keterampilan tata kecantikan rambut, peserta didik akan meningkatkan pendapatan.dimana kecakapan hidupnya untuk peserta pelatihan kursus di LKP Henny's pada usia produktif, dapat dikemukakan meliputi (1) pengetahuan dan keterampilan yang dimiliki lulusan sebagai hasil belajar pelatihan tata kecantikan rambut yang ditempuhnya, (2) para lulusan memanfaatkan hasil pelatihan tata rias rambut dalam rangka memperoleh penghasilan untuk kelangsungan hidupnya, (3) hasil yang diperoleh dari pemanfaatan hasil pelatihan tata kecantikan rambut, (4) upaya pengembangan usaha serta kesulitan yang dialaminya.

Menurut Ibu eva selaku lulusan pelatihan tata kecantikan rambut, program pelatihan tata kecantikan rambut sangat membantu masyarakat terutama masyarakat dengan taraf ekonomi rendah, hal tersebut dapat dikatakan karena ibu eva yang dulunya hanya penjual gorengan keliling dengan penghasilan bersih nya hanya Rp.500.000/bulan kini beliau membuka usaha salon rambut di rumahnya dengan penghasilan bersih sekitar Rp.2.0000.000/bulan. Hal itu membuat program tata kecantikan rambut dalam pendapatan masyarakat dapat dikatakan berhasil.

\section{Pembahasan}

Proses untuk mewujudkan sumber daya manusia yang unggul dan kompeten memang sulit, hal itu harus dilakukan dengan cara merubah pola pikir masyarakat agar berpikir dinamis. Pada kondisi masyarakat sekitar LKP Henny's saat ini perlu adanya upaya menciptakan kondisi agar masyarakat mampu untuk berpikir dinamis. LKP Henny's dan pemerintah telah melakukan upaya tersebut dengan menyelenggarakan pelatihan yang bertujuan untuk mengembangkan keahlian masyarakat, mengubah mindset masyarakat, mengembangkan sikap, sehingga dapat meningkatkan pendapatan masyarakat dengan bekerja maupun memiliki usaha. Hal ini sejalan dengan pendapat (Moekijat, 2002) menyebutkan bahwa tujuan pelatihan adalah untuk : 1) Mengembangkan keahlian, sehingga pekerjaan dapat diselesaikan dengan lebih cepat dan lebih efektif; 2) Mengembangkan pengetahuan, sehingga pekerjaan dapat dikerjakan secara rasional; dan 3) Mengembangkan sikap, sehingga menimbulkan kemampuan kerjasama dengan teman-teman pegawai dan dengan pimpinan.

Salah satu keterampilan yang di selenggarakan di LKP Henny's melalui pendidikan kecakapan hidup atau life skills adalah keterampilan Tata Kecantikan Rambut. Keterampilan Tata Kecantikan Rambut adalah salah satu bentuk pendidikan yang dikembangkan pada pendidikan nonformal untuk melayani kebutuhan belajar masyarakat. Program pembelajaran keterampilan Tata Kecantikan Rambut dilaksanakan dalam rangka membelajarkan masyarakat, terutama bagi masyarakat yang berada dalam taraf ekonomi rendah.

Jadi kegiatan pelatihan tata kecantikan rambut merupakan upaya nyata peran dari berbagai pihak demi membantu masyarakat agar berdaya, adanya kegiatan pelatihan tata kecantikan rambut ini memberikan beberapa manfaat, diantaranya :

a. Menambah keahlian masyarakat untuk bekal berwirausaha mandiri maupun bekerja.

b. Meningkatkan pendapatan masyarakat

c. Menjadikan masyarakat berdaya dan berbudi pekerti luhur.

Dalam pelaksanaan nya pelatihan tata kecantikan rambut juga memiliki faktor penghambat yaitu lahan pembelajaran yang terlalu sempit untuk peserta 40 orang, 
belum lagi peralatan praktek yang memakan tempat cukup luas sehingga pada saat pembelajaran praktek, terlihat kurang kondusif karena dilaksanakan berkelompok dan waktu yang dibutuhkan pun menjadi lama. Hal ini mungkin juga dikarenakan bagian halaman depan yang biasanya juga dipakai untuk praktek sedang di renovasi sehingga hal tersebut dapat terjadi.

\section{KESIMPULAN}

Konsep kontribusi pengembangan keilmuan Pendidikan Masyarakat terutama dalam memperkaya kajian pendidikan nonformal dalam pengembangan pembelajaran kecakapan hidup khusus nya di bidang keterampilan Tata Kecantikan Rambut berdampak nyata bagi masyarakat. Salah satu upaya dalam meningkatkan pendapatan masyarakat yaitu melalui pelatihan tata kecantikan rambut. Di lihat dari segi efektifitas program, program ini memberi aura positif bagi masyarakat dan juga membuat masyarakat termotivasi untuk mengubah nasib mereka menjadi lebih baik. Kegiatan pelatihan tata kecantikan rambut dilaksankan melalui beberapa tahap, yaitu: pembelajaran teori, pengenalan dasar mengenai tata kecantikan rambut, pengantar ilmu kewirausahaan, pengenalan bahan bahan dan alat kerja, pengenalan resiko bekerja, penanganan customer, handling complaint, dll yang dilakukan selama seminggu. Lalu pembelajaran praktek yang dilakukan selama 3 minggu adalah mengaplikasikan teori yang sudah diajarkan untuk di praktekan terhadap rekan se-kelompok. Mulai dari pengaplikasian bahan kerja,alat kerja, teknik memotong, creambath, catok, dll. Adapun masukan berupa prinsip dasar perumusan kebijakan di bidang pendidikan, sebagai salah satu strategi pengembangan sumber daya manusia.

\section{DAFTAR PUSTAKA}

Anwar. (2012). Pendidikan Kecakapan Hidup (life Skill Education. Bandung: Alfabeta.

Ansori, A \& Saepudin, A. (2013). TRANSFORMASI PEMBELAJARAN DI PENDIDKAN NON FORMAL (Upaya mempersiapkan pendidik dan peserta didik dalam menghadapi tantangan global untuk menjadi manusia pembelajar). Empowerment, 2(1), 1-15

Boediono. (1992). Teori Pertumbuhan Ekonomi. Yogyakarta: BPFE UGM.

Herdiansyah, H. (2010). Metode Penelitian Kualitatif untuk Ilmu-ilmu Sosial. Jakarta: Salemba Humanika.

Kamil, M. (2010). Model Pendidikan dan Pelatihan (Konsep dan Aplikasi). Bandung: Alfabeta.

Moekijat. (2002). Evaluasi Pelatihan Dalam Rangka Peningkatan Produktivitas(Perusahaan). Bandung: Mandar Maju.

Nirmalasari, $\mathrm{T}$ \& Widiastuti, N. (2018). PERAN TOKOH PEMUDA DALAM MENINGKATKAN PARTISIPASI KARANG TARUNA DI DESA NANJUNG MARGAASIH. Comm-Edu (Community Education Journal). 1(2), 94-104

Saepudin \& Mulyono. (2019). COMMUNITY EDUCATION IN COMMUNITY DEVELOPMENT. Empowerment, 8(1), 65-73

Salim, E. (1996). Aspek Sikap Mental Dalam Manajemen Sumber Daya Manusia. Jakarta: Ghalia Indonesia. 
Sudjana, D. (2010). Metode dan Teknik Pembelajaran Partisipasif. Bandung : Falah Production. 